\title{
THE EFFECTS OF ILL-HEALTH AND DISABILITIES ON LABOUR FORCE PARTICIPATION AMONG NIGERIAN HOUSEHOLDS.
}

\author{
Rolle Remi Ahuru*1, Efegbere Henry Akpojubaro ${ }^{2}$ \\ ${ }^{1}$ Department of Economics, Faculty of Social Sciences, University of Benin, Edo State, \\ Nigeria \\ ${ }^{2}$ Department of Community Medicine, College of Medical Sciences, Edo University \\ lyamho, Edo State, Nigeria \\ Remirolle1986@yahoo.com \\ Henryefegbere@gmail.com
}

\begin{abstract}
Nigeria has demeaning health statistics together with declining labour supply despite the large population size. This paper investigated the effect of illness, disability and other socio-demographic factors on labour force participation among Nigerian households. This study is cross-sectional in which secondary data from the General Household Survey (2015/2016) was used for the analysis. A representative sample of 4,200 household heads was used for the analyses. Both predictive and descriptive analyses were undertaken. Binary logistic regression was used to investigate predictors of labour force participation among the household heads. The data revealed that $52.1 \%$ of respondents were engaged in labour force. Controlling for other variables, the various forms of disabilities, ill-health, body injury, gender and educational attainment were significant determinants of labour force participation. The result provokes the need for policymakers to articulate policies that improve access to healthcare through the expansion of health insurance coverage. The study concluded that self-assessed health and education attainment influence labour force participation. Policies should be used to expand educational opportunities and improve access to healthcare services in Nigeria. To improve access to healthcare, the Nigeria government should increase the ownership of health insurance policy by broadening the coverage of the formal health insurance and encouraging community-based health insurance in the informal and rural sectors.
\end{abstract}

Keywords: III health, disabilities, labour force participation, Nigerian households.

JEL: D6, H8, R4.

\section{Introduction}

Health status is the general wellbeing of a person at a point in time. Health is not the mere absence of infirmity or diseases, but a state of complete mental, physical and social wellbeing (WHO, 2006). The level of labour force participation is limited for countries with poor health status given that many sick people have a low probability of being engaged under prevailing wages (Cai, 2007). Poor health status means that the health of the citizens of the nations is low at a particular point in time. In nations with deplorable health outcomes, people in that country require improved access to healthcare services. More so, poor health status implies that individuals will have low productivity. Low productivity reduces an individual's earnings power and therefore discourages him/her from participating in the labour market. The health indicators of Nigeria have remained largely below the country's targets and internationally-set benchmark due to weakness inherent in the health system (United

* Corresponding author: Rolle Remi Ahuru 
Nations Development Programme, UNDP, 2014; Rolle, Osaze and Henry, 2020).HIV and Malaria are co-epidemics that continue to plague the health of Nigerians (Rolle and Onwuma,2019). HIV/AIDS and Malaria are the two main causes of morbidity and mortality among Nigerians. Approximately, $97 \%$ of Nigerians populations are at the risk of Malaria attack and $1.5 \%$ of Nigeria adults aged $15-49$ are currently living with HIV infection (World Development Indicators, 2018). Several other non-communicable diseases such as hypertension, sick cell diseases, anaemia, mental health, blindness, stroke account for Nigeria's high disease burden (National Strategic Health Development Plan (SHDP, 2010, Rolle, Osaze and Henry, 2020).

In Nigeria, there is a dearth of studies that examined the effect of health on labour force participation using a microeconomic approach. The few studies either utilized a microeconomic approach (see Ajani and Ugwu, 2008; Omonona, Egbetokun and Omiolele, 2012) or a macroeconomic approach to examine the effect of health on labour productivity (see Jimoh, 2005; Umoru and Yaqub, 2013; Rolle and Iseghohi, 2018; Onyema and Nyenke, 2019). Given the high rate of disease infection and low labour supply compared to an immeasurable increase in population size, it is essential to examine the effect of poor health status on labour force participation among Nigerian households. The study drew upon data from the most recent General Household Survey (2015-2016) wave 3 to examine the phenomenon. It examined the effect of various dimensions of self-assessed health (that is illness and disability) on labour force participation among Nigerian households.

The purpose of this study goes beyond estimating the impact of health status on labour force participation among Nigerian households to include making available important and current information on the issue at stake. As a result, the study would be relevant to those who would be making, interpreting or implementing policies on health and its impact in the country. This study would, therefore, bring to the knowledge of government at all levels, the economic need to invest in the health of workers by providing them with adequate health facilities at reduced (or subsidized) cost since adverse health reduces the productivity of the nation's workforce.

The remainder of the paper is structured as follows: section 2 focuses on literature review; section 3 presents the methods and materials, section 4 dwells on the results, section 5 on the Discussion of the results and section 6 concludes the study.

\section{Literature Review}

\subsection{Theoretical Literature Review}

Grossman's $(1972,2000)$ model on the demand for health exposited on the relationship among individual's health, human capital and labour force participation. The model built on the Becker' (1964) model on human capital theory. According to this model, an individual's health stock determines the total amount of time the individual engaged in labour, while his stock of knowledge determines his market and non-market productivity (Grossman, 2000). According to Becker (1964), an individual's current health stock depends on past investment made on health and the rate of depreciation of health stock. Health is both consumption and production goods. As consumption goods, it enters into an individual's utility function given that there is a psychic utility associated with being healthy. As production goods health is an essential input in the production process since it frees up streams of healthy time utilized in producing both health and non-health goods (Novignon, Novignon and Arthur, 2015). However, an individual's health stock diminishes over time approaching a threshold level where death may occur, but the rate of depreciation may be slowed down through appropriate investment in health, which includes medicare, good dieting, housing facilities and sleep (Grossman, 1972). The pure investment model analyses health capital as an 
output generated from time allocated to health production, hence good health provides extra time to engage in productive activities that determine income levels over an individual's lifetime (Novignon Novignon and Arthur, 2015).

\subsection{Empirical Literature Review}

The relationship between health and labour force participation has attracted several research works. Various researchers employed different research methods and measures of both health status and labour force participation to examine this relationship (Novignon et al; 2015).

Kalwij and Vermeulen (2005) studied labour force participation of the elderly for eleven countries in Europe and found that different health indicators had different significantly impact on the decision of the elderly to participate in the labour force and that health effects differ between countries. The study utilized both subjective measures of health (selfassessed health) and objective health measures (body mass index and bad mental health) for individuals aged (50-64) years. Using descriptive analysis, they observed that improved health conditions may yield 10 percentage points higher for men than women in some European countries under study, while in other countries studied, participation would be higher for females with improved health than males.

Thomas and Thierry (2006) analyzed disability and labour force participation of older workers using a latent variable model. In a preliminary step, they estimated an equation of participation by directly introducing the self-reported disability, but the "true" disability status was unobserved. In a second step, following Bound's (1991) methodology, they used estimations of self-reported disability and observed that using a self-reported health measure leads to a downward bias in the impact of disability status on labour force participation.

Cai (2007) examined the relationship between health and labour force participation in Australia. The study adopts the method of simultaneous equation panel model using Full Information Maximum Likelihood Criterion and two-stage least square to observe the relationship between self-assessed health and labour force participation for both males and females. Drawing upon data from HILDA data, it was observed that health had a significant positive effect on labour force participation.

Mushtaq, Mohsin and Zaman (2013) investigated the effects of health on labour force participation for Pakistan for the period (1975-2011). The study employed the Autoregressive Distributed Lag Model cointegration technique to estimate both short-run and long-run elasticities, whereas the Wald coefficient restriction test was used to determine the dynamic relationship between the variables. The study revealed that health significantly influences labour force participation, however, Pakistan could not derive maximum benefit from human capital development due to poor health outcomes.

Belachew and Kumar (2014) in their study draw upon data from five National Health Surveys (NHSs) of Australia to examine the association between self- assessed health status and labour force participation utilizing logistic regression model, and controlled for other variables such as age, period and cohorts. Their results showed a significant positive association between health status and labour force participation, with the effects stronger for female than male. There was also a strong negative relationship between major chronic diseases (arthritis, cancer, asthma, diabetes and heart disease) on both male and female's labour force participation. They also reported cohorts effect for both male and female, with lower probability to participate in the labour force noticed among the youngest cohorts.

Dogrul (2015) examined the effect of health status on labour force participation in Turkey utilizing a two-stage estimation technique for a cross-sectional data and found out that health status significantly affects labour force participation for all age-gender groups. Also, a reverse causality was noted flowing from labour force participation to health, showing there 
is a psychic utility in being engaged economically. However, its findings that labour force participation positively influenced health contradicts that of Cai's(2007) findings that labour force participation had a negative effect on the health status of men.

Novignon et al (2015) used objective health indicator-life expectancy as a proxy for health status to examine the relationship health status and labour force participation in SSA by employing a dynamic panel model using the generalized method of moments. The result shows a significant effect of health status on female labour force participation across SSA countries.

Irequi Bohorquez, Melo -Becerra, and Teressa (2016) examined the relationship between health status and labour force participation drawing data from the first wave of the Columbian Longitudinal Survey. The estimation technique addressed possible potential endogeneity between the two variables. The results revealed two-way relationships between health status and labour force participation so that healthy people were more likely to engage in labour force participation, and those who engaged in the labour force were more likely to be healthier. However, significant differences were uncovered when separate analyses were undertaken for separate age groups and gender. The results highlight the importance of public policy to improve good health and consequently improve labour force participation and economic growth performance.

\section{Materials and Method}

\subsection{Theoretical Framework}

The study adopts the theoretical framework from Currie and Madrina (1999) in Novignon et al (2015), which follows the pioneering work on human capital by Becker (1964), and Grossman (1972) and was utilized by Novignon et al (2015). According to this model, the consumer maximizes an intertemporal utility function, which is specified as:

$$
\begin{gathered}
\sum_{t}^{T} \operatorname{Et}\left(1 /(1+\delta)^{\mathrm{t}} \mathrm{Ut} \beta(\mathrm{At}+1)\right. \\
\text { Where } \delta=\text { discount rate, } \\
\mathrm{B}(.)=\text { bequest function } \\
\mathrm{A}=\text { assets } \\
\mathrm{U}=\text { utility function given below: }
\end{gathered}
$$

In equation (2), Ht represents the stock of health, Ct represents consumption of non-health goods, Lt is leisure, $\mathrm{Xt}$ is the vector of exogenous taste shifters, Ut is a vector of permanent individual-specific taste shifters, and et denotes a shock to preferences. The individual's utility function in equation (2) is maximized subject to the set of constraints in equation (3) through equation (7):

$$
\begin{aligned}
& \mathrm{Ht}=\mathrm{Ht}\left(\mathrm{Ht}-1, \mathrm{Gt}, T h, \mathrm{Zt}, \mathrm{U}_{2}, \mathrm{e}_{2} \mathrm{t}\right) \\
& \mathrm{Ct}=\mathrm{Yt}+\mathrm{pt} \mathrm{Gt}-(\mathrm{At}-\mathrm{At}+1) \\
& \mathrm{Yt}=\mathrm{Wt}+\mathrm{rAt} \\
& J=\mathrm{T}_{\mathrm{L}}+T h+T s \\
& \mathrm{Ts}=\mathrm{Ts}\left(\mathrm{Ht}, \mathrm{U}_{3}, \mathrm{e}_{\mathrm{st}}\right)
\end{aligned}
$$

Where $\mathrm{Ht}-1$ is one time-lagged value of health stock, Gt is health goods e.g. medicare, Th is time engaged in producing health (that is the time involved in an exercise, diet, sleeping), $\mathrm{Zt}$ is other goods that can enhance health e.g. food, $\mathrm{U}_{2}$ is individual specific productivity shifters, e 2 t is productivity shock, Yt represents income, $\mathrm{P}$ represents price, (At - At+1) represents the change in assets, At is asset in the current period, Wt is the wage, $r$ is the 
interest rates, $\int$ is total time allocation, $\mathbf{T}_{\mathbf{L}}$ is time engaged in leisure, $T s$ is time spent in sickness, $\mathrm{U}_{3}$ is individual determinants of health and $\mathbf{e}_{\mathbf{s t}}$ is a random disturbance that may influence health (pandemics)(Currie and Madrina, 1999 in Novignon et al; 2015). By solving the utility-maximizing problem above, conditional labour supply function is deduced, which depends on the stock of health.

\subsection{Data Source}

The Data analyzed in this study was drawn from the General Household Survey (GHS, 2015/2016) wave 3 . GHS is a nationally representative data collected every 2-3 years. The collection is pioneered by the National Bureau of Statistic with support from World Bank and National Planning Commission. Data collection is done at two visits that are post-planting and post-harvest seasons. The survey follows the same households over time and collects information on diverse areas. The survey data has national coverage covering the 36 States and the Federal Capital Territory (FCT). The sample design for the survey facilitated the provision of estimates at the national and subnational levels (national, zone and States). The multi-stage stratified sampling design was utilized in collecting the data. In the first stage, 60 enumerations (EAs) were selected from the 36 States and FCT. In stage 2, ten households were selected per EAs using systematic sampling procedure. Hence, a total of 22,000 households were marked for the survey. Out of these, 5000 households were selected from the 500 EAs. A total of 4,916 households completed their interviews with a non-response rate of $1.68 \%$. Given the panel structure of the GHS, in which a set of households were interviewed post-planting and post-harvest, some households moved before the wave 3 interview. Hence, 4,581 households that are 32,827 household members were interviewed in the post-harvest wave 3.

Data collection involved the training of field data collectors on the ethics of the research and procedure of data collection. Each household was surveyed by interviewers, supervisors and operators. Interviewers administered the questionnaires and submitted the filled questionnaires to Supervisors for cross-checking. At the end of each day, Supervisors handed over the questionnaires to operators. Operators were expected to report any perceived errors. Where necessary, supervisors demanded re-interview. Data collection was done using computer-assisted personal interviewing (CAPI) for entry of data. CAPI fasttracked data collection and enhanced accuracy in data collection.

\subsection{Outcome Indicator}

The outcome indicator in this study is labour force participation. Labour force participation is defined as engaging in economic activities as a means of sustenance. In the General Household Survey (2015/2016), three questions were asked to elicit information from respondents' labour force participation. For the past seven days, respondents were asked if they undertook any of the followings: (i) Working as self-employed in any venture with a means of sustenance (ii) worked on a farm owned or rented by a member of the household, either in cultivating crops or in other farming tasks for livestock (iii) has worked on his/her own account in a business enterprise owned by his/herself or someone else. Household heads who reported to undertake any of the three were concluded to participate in the labour force, hence coded 1 , while otherwise coded 0 .

\subsection{Health Indicators}

The health indicators cut across illness, bodily injury and health limitations (HLLs). An individual was considered ill if they reported they visited physicians for any known illness such as malaria, cough, and others. Bodily injury is defined as burnt or bone fractures that reduce an individual's quality of lives. HLLs adopted a self-assessed approach in which an individual reported on various disabilities associated with daily living. The following 
limitations were considered: (i) difficulties in walking (ii) difficulties in running (iii) difficulties in stooping/bending (iv) memory lapse/difficulties in concentration (v) difficulties in hearing despite hearing aid (vi) sight challenge.

\subsection{Other Socio-demographic Factors}

The study aims at investigating the influence of self-assessed health status on labour force participation among Nigerian households. In addition to health status (the treatment variable), six socio-demographic factors were considered: age, educational attainment, sex of head of households, marital status, type of occupation and household size. Age in years measures the current age of the respondents. It was reported in continuous terms. However, we recoded age into the following groups: 15-24, 25-34, 35-44, 45-54, and 55-64. Marital status examined the current marital status of head of households. The following categories were considered: Single, Married, Divorced, Separated, and Widowed. Educational qualifications measure the current educational attainment of the respondents. We considered the following categories: no formal, primary, secondary and tertiary education. Gender distinguished male from female. Place of residence examined the current location of respondents. We considered rural and urban residence. Occupation examined the sector where the head of the household worked. The following groups were considered: Agriculture, Services, Others, Manual and Professional.

\subsection{Statistical Analysis}

Data were analyzed using STATA version 13.0 for windows. Frequency tables were generated and Univariate analysis was conducted to generate crude odds ratio for the dependent variable labour force participation. The factors that were significant at $10 \%$ were entered into the binary logistic regression model to generate adjusted odds ratio at $95 \%$ confidence intervals.

\section{Analysis}

\subsection{Results}

The preliminary analysis of this study aims at giving an overview by establishing descriptive statistics of some selected variables. The descriptive statistics is a summary statistics of all variables used in the study. The result shows that on average, $52.1 \%$ of the respondents were engaged in the labour force. While male accounts for $48.3 \%$, female category accounted for $51.7 \%$. Furthermore, $15.2 \%$ from the sample were ill and $6.2 \%$ reported they suffered bodily injury. On average, 3.5 persons reported they had one form of disabilities (that are, hearing impairment, sight problem, difficulty in running, walking and memory/lack of concentration). Majority of the respondents belonged to the age group (15-24) years (34.1\%). Approximately, $46 \%$ of households represented reported between 1 and 4 persons as family size. While urban residents account for $42.1 \%$, rural accounts for $57.9 \%$. Analysis of educational attainment revealed that the majority of household heads had only primary educational qualification (53.1\%). Approximately, 40.1\% were currently married and living with their partners. Most of the partners were engaged in the Agricultural sector $(40.2 \%)$. 
Table 1: Summary Statistics of Variables

\begin{tabular}{|c|c|c|c|}
\hline \multicolumn{2}{|c|}{ Variables } & \multirow{2}{*}{$\begin{array}{c}\text { Number } \\
2,188\end{array}$} & \multirow{2}{*}{$\begin{array}{c}\text { Percentage } \\
52.1\end{array}$} \\
\hline Labour force participation: & Yes & & \\
\hline & No & 2,012 & 47.9 \\
\hline \multirow[t]{2}{*}{ Gender: } & Male & 2,029 & 48.3 \\
\hline & Female & 2,171 & 51.7 \\
\hline \multirow[t]{5}{*}{ Current age: } & $15-24$ & 1,432 & 34.1 \\
\hline & $25-34$ & 764 & 18.2 \\
\hline & $35-44$ & 538 & 12.8 \\
\hline & $45-54$ & 831 & 19.8 \\
\hline & $55-64$ & 635 & 15.1 \\
\hline \multirow[t]{2}{*}{ Illness: } & No & 3,562 & 84.8 \\
\hline & Yes & 638 & $15 . .2$ \\
\hline \multirow[t]{2}{*}{ Bodily injury: } & No & 3,939 & 93.8 \\
\hline & Yes & 261 & 6.2 \\
\hline \multirow[t]{2}{*}{ Difficulties in hearing } & No & 1,927 & 45.9 \\
\hline & Yes & 2,273 & 54.1 \\
\hline \multirow[t]{2}{*}{ Difficulties bending/stooping : } & No & 1,171 & 27.9 \\
\hline & Yes & 3,028 & 72.1 \\
\hline \multirow[t]{2}{*}{ Difficulties in running: } & No & 1,465 & 34.9 \\
\hline & Yes & 2,735 & 65.1 \\
\hline \multirow{2}{*}{$\begin{array}{l}\text { Memory lapse /difficulties in } \\
\text { concentration: }\end{array}$} & No & 2,385 & 56.8 \\
\hline & Yes & 1,815 & 43.2 \\
\hline \multirow[t]{2}{*}{ Difficulties in walking: } & No & 1,834 & 43.7 \\
\hline & Yes & 2,366 & 56.3 \\
\hline \multirow[t]{2}{*}{ Sight challenge : } & No & 1,731 & 41.2 \\
\hline & Yes & 2,469 & 58.8 \\
\hline \multirow[t]{2}{*}{ Household size : } & $1-4$ & 1,916 & 45.6 \\
\hline & $\geq 5$ & 2,284 & 54.4 \\
\hline \multirow[t]{5}{*}{ Marital status: } & Single & 859 & 20.5 \\
\hline & Married & 1,684 & 40.1 \\
\hline & Divorce & 341 & 8.1 \\
\hline & Separated & 528 & 12.6 \\
\hline & Widowed & 788 & 18.8 \\
\hline \multirow[t]{2}{*}{ Place of residence: } & Rural & 2,432 & 57.9 \\
\hline & Urban & 1,768 & 42.1 \\
\hline \multirow[t]{4}{*}{ Educational attainment: } & No formal education & 658 & 15.7 \\
\hline & Primary education & 2,229 & 53.1 \\
\hline & Secondary education & 789 & 18.8 \\
\hline & Tertiary education & 524 & 12.5 \\
\hline \multirow[t]{5}{*}{ Occupation: } & Agriculture & 1,687 & 40.2 \\
\hline & Services & 705 & 16.8 \\
\hline & Others & 519 & 12.3 \\
\hline & Manual & 794 & 18.9 \\
\hline & Professional & 495 & 11.8 \\
\hline
\end{tabular}




\subsection{Analysis of the Model}

In Table 2, the logistic regression outputs for both the unadjusted and the adjusted models are presented. For the adjustment model, predictors of labour force participation include gender, illness, bodily injury, difficulties in hearing, difficulties in bending/stooping, difficulties in running, memory lapse and educational attainments. In reference to female respondents, male respondents (aoR: 1.98, 95\% Cl: 1.11-2.42] were approximately two times more likely to engage in the labour force. Respondents who reported no illness (aOR: $1.64,95 \% \mathrm{Cl}$ : 1.14-1.98] were $64 \%$ significantly more likely to engage in the labour force. Being free from various health limitations: difficulties associated with hearing [aOR: $4.18,95 \% \mathrm{Cl}: 0.31-1.04$ ]; bending/stooping [aOR: $1.98 ; 95 \% \mathrm{Cl}: 0.41-1.31$ ]; running [aOR: $3.18,95 \% \mathrm{Cl}: 0.18-0.91$ ]; memory lapse [aOR: $1.42,95 \% \mathrm{Cl}: 1.04-1.08$ ] and walking [aOR: $2.31,95 \% \mathrm{Cl}: 1.04-1.08]$ significantly improves the chances to engage in labour force. Absence of body injury [aOR: $3.11,95 \% \mathrm{Cl}: 1.14-1.98$ ] significantly improves the chances of engaging in the labour force. In reference to the uneducated, secondary education [aOR: $1.92,95 \% \mathrm{Cl}: 0.48-1.72$ ] and tertiary education [aOR: $2.08,95 \% \mathrm{Cl}: 0.98-2.41]$ significantly improves the chances of labour force participation.

Table 2: Factors Associated with Labour Force Participation among Respondents

\begin{tabular}{|c|c|c|c|c|}
\hline Variables & Yes N (\%) & No $\mathbf{N}(\%)$ & $\begin{array}{c}\text { Unadjusted } \\
\text { Odds Ratio } \\
(95 \% \mathrm{Cl})\end{array}$ & $\begin{array}{c}\text { Adjusted } \\
\text { Odds Ratio } \\
(95 \% \mathrm{Cl})\end{array}$ \\
\hline \multicolumn{5}{|l|}{ Gender: } \\
\hline Female (ref) & $666(30.7)$ & $1,505(69.3)$ & 1.00 & 1.00 \\
\hline Male & $1,522(75.0)$ & $507(25.0)$ & $2.41(0.42-1.38)^{\star \star}$ & $1.98(1.11-2.42)^{\star}$ \\
\hline \multicolumn{5}{|l|}{ Current age: } \\
\hline $15-24$ (ref) & $716(50.0)$ & $716(50.0)$ & 1.00 & ……....... \\
\hline $25-34$ & $531(69.5)$ & $233(30.5)$ & $1.81(0.31-0.98)$ & $\ldots \ldots \ldots \ldots \ldots . .$. \\
\hline $35-44$ & $323(60.0)$ & $215(40.0)$ & $1.91(1.42-2.41)$ & …........... \\
\hline $45-54$ & $332(39.9)$ & $499(60.1)$ & $2.42(1.64-2.98)$ & $\ldots \ldots \ldots \ldots \ldots .$. \\
\hline $55-64$ & $127(20.0)$ & $508(80.0)$ & $3.72(1.98-3.71)$ & ……….... \\
\hline \multicolumn{5}{|l|}{ Illness: } \\
\hline Yes (ref) & $575(90.1)$ & $63(19.9)$ & 1.00 & 1.00 \\
\hline No & $1,613(45.3)$ & $1,949(54.7)$ & $3.81(1.32-1.48)^{*}$ & $1.64(1.14-1.98)^{\star \star}$ \\
\hline \multicolumn{5}{|l|}{ Bodily injury: } \\
\hline Yes(ref) & $227(87.0)$ & $34(13.0)$ & 1.00 & 1.00 \\
\hline No & $1,961(49.8)$ & $1,978(50.2)$ & $1.91(0.34-1.71)^{\star \star}$ & $3.11(1.14-1.98)^{\star \star}$ \\
\hline \multicolumn{5}{|l|}{$\begin{array}{l}\text { Difficulties in } \\
\text { hearing: }\end{array}$} \\
\hline Yes (ref) & $824(42.8)$ & $1,103(57.2)$ & 1.00 & 1.00 \\
\hline No & $1,364(60.0)$ & $909(40.0)$ & $1.39(0.98-2.41)^{\star}$ & $4.18(0.31-1.04)^{\star}$ \\
\hline \multicolumn{5}{|l|}{$\begin{array}{c}\text { Difficulties in } \\
\text { bending/stooping }\end{array}$} \\
\hline Yes (ref) & $878(74.9)$ & $293(25.1)$ & 1.00 & 1.00 \\
\hline No & $1,310(43.3)$ & $1,719(56.7)$ & $2.83(1.41-3.19)^{*}$ & $1.98(0.41-1.31)^{\star \star}$ \\
\hline \multicolumn{5}{|l|}{$\begin{array}{l}\text { Difficulties in } \\
\text { running: }\end{array}$} \\
\hline Yes(ref) & $1,136(41.5)$ & $1,599(58.5)$ & 1.00 & 1.00 \\
\hline No & $1,052(71.8)$ & $413(28.2)$ & $3.28(0.62-1.91)$ & $1.31(0.04-2.08)$ \\
\hline
\end{tabular}


Oradea Journal of Business and Economics, Volume V, Issue 2

Published on September 2020

\begin{tabular}{|c|c|c|c|c|}
\hline $\begin{array}{c}\text { Memory } \\
\text { lapse/Concentration } \\
\text { difficulties }\end{array}$ & & & & \\
\hline Yes (ref) & $1,188(65.5)$ & $627(34.5)$ & 1.00 & 1.00 \\
\hline No & $1,000(41.9)$ & $1,385(58.1)$ & $1.87(2.41-3.65)^{*}$ & $1.42(1.04-1.08)^{*}$ \\
\hline \multicolumn{5}{|l|}{$\begin{array}{l}\text { Difficulties in } \\
\text { walking: }\end{array}$} \\
\hline Yes(ref) & $1,136(48.0)$ & $1,230(52.0)$ & 1.00 & 1.00 \\
\hline No & $1,052(57.4)$ & 782(42.6) & $1.98(0.42-1.31)^{*}$ & $2.31(1.04-1.08)^{\star \star}$ \\
\hline \multicolumn{5}{|l|}{ Sight challenge: } \\
\hline Yes(ref) & $717(29.0)$ & $1,752(71.0)$ & 1.00 & ................ \\
\hline No & $1,471(84.9)$ & $260(15.1)$ & $1.41(1.31-3.41)$ & $\ldots \ldots \ldots \ldots \ldots$ \\
\hline \multicolumn{5}{|l|}{ Household size } \\
\hline $1-4$ (ref) & $375(19.6)$ & $1,541(80.4)$ & 1.00 & n........... \\
\hline$\geq 5$ & $1,813(79.4)$ & $471(20.6)$ & $1.91(0.41-2.18)$ & ….......... \\
\hline \multicolumn{5}{|l|}{ Marital status: } \\
\hline Single(ref) & $515(59.9)$ & $344(40.1)$ & 1.00 & $\ldots \ldots \ldots \ldots \ldots$ \\
\hline Married & $688(40.9)$ & $996(59.1)$ & $0.41(0.32-1.98)$ & …............ \\
\hline Divorce & $164(48.1)$ & $177(51.9)$ & $1.21(0.18-1.19)$ & ............... \\
\hline Separated & $380(71.9)$ & $148(28.1)$ & $1.18(0.42-2.13)$ & $\ldots \ldots \ldots \ldots \ldots$ \\
\hline Widow & $441(55.9)$ & $347(44.1)$ & $2.41(0.98-1.42)$ & .............. \\
\hline \multicolumn{5}{|l|}{$\begin{array}{l}\text { Educational } \\
\text { attainment: }\end{array}$} \\
\hline No formal(ref) & $342(51.9)$ & $316(48.1)$ & 1.00 & 1.00 \\
\hline Primary & $864(38.8)$ & $1,365(61.2)$ & $1.21(1.11-1.98)^{\star *}$ & $1.81(0.42-1.32)$ \\
\hline Secondary & $537(68.1)$ & $252(31.9)$ & $2.31(1.41-2.31)^{\star \star}$ & $1.92(0.48-1.72)^{\star \star}$ \\
\hline Tertiary & $445(84.9)$ & $79(15.1)$ & $3.48(1.31-3.42)^{*}$ & $2.08(0.98-2.41)^{*}$ \\
\hline \multicolumn{5}{|l|}{ Occupation: } \\
\hline Agriculture(ref) & $240(14.2)$ & $1,447(85.8)$ & 1.00 & $\ldots \ldots \ldots \ldots$ \\
\hline Services & $599(84.9)$ & $106(15.1)$ & $1.11(1.11-2.12)$ & .............. \\
\hline Others & $389(74.9)$ & $130(25.1)$ & $1.21(1.31-2.42)$ & ….......... \\
\hline Manuals & $683(86.0)$ & $111(14.0)$ & $3.48(1.98-2.93)$ & $\ldots \ldots \ldots \ldots$ \\
\hline Professionals & $277(55.9)$ & $218(44.1)$ & 4.32(1.64-3.18) & ............. \\
\hline
\end{tabular}

${ }^{*} \mathrm{p}<0.05^{* *} \mathrm{p}<0.01{ }^{* * *} \mathrm{p}<0.001$.ref: reference category; Cl: Confidence Interval

N.B number in parenthesis represents a simple percentage.

\section{Discussion of the Results}

This study examined the influence of health status, which comprises illness, body injury and various forms of disabilities on labour force participation among 4,200 head of households drawn from the most recent General Household Survey (2015/2016) wave 3.The study was premised on the assumption that various dimensions of ill-health can discourage participation in the labour market. Illness can retard labour productivity and reduce labour earnings, thereby creating a disincentive for sick people to engage in the labour market.

Findings from the study revealed the role of ill-health, body injury and various limitations associated with daily livings on labour force participation. All the indicators used to proxy disabilities except sight challenge were significantly associated with lower odds for participating in the labour force. Respondents who reported absence of ill-health were approximately two times significantly more likely to engage in the labour force. Our results 
conform to findings from past studies (Novignon et al; 2015; Cai and Kalb, 2004; Dogrul, 2015; Nwosu and Woolard, 2015; Belachew and Kumar, 2014; Thomas and Thierry, 2006). The results showed that male respondents were more likely to participate in the labour force. It can be seen that male respondents were approximately two times more likely to participate in the labour force when compared to female respondents. This is typical of Nigerian settings where women are seen as home keepers. In Nigeria, gender norms defined the role of men as financiers and that of women as home managers. This finding conforms to a study conducted for SSA (Novignon et al; 2015).

The result showed that education significantly improves the chances of labour force participation. Specifically, respondents who had secondary and tertiary educational qualifications were respectively $92 \%$ and $108 \%$ significantly more likely to participate in the labour force. This result is not surprising given that most formal employments require certificates to be employed. Also, school offers the opportunity for people to acquire skills needed to be gainfully employed. The finding conforms to reports from past studies (Mushtag et al; 2013; Novignon et al; 2015).

\subsection{Policy Recommendation}

The results from the analyses provoke the need to articulate policies that will improve the health status of Nigerians given the pivotal place of health in enhancing labour productivity and economic growth. While participating in the labour market is influenced by health, labour force participation improves the state of well-being. Pragmatic policies, such as health insurance schemes, should be put in place to improve the health status of the Nigerian population. Such health policies will improve people's access to modern care services by diffusing the cost of treatment across people and over time. There is no gain reaffirming the health wealth led hypothesis, which posits that healthier people are wealthier people. More so, the government should encourage employer-sponsored health insurance in which employers should either pay the premium on behalf of the employees or engage in sharing the premium with employees.

\subsection{Strength and Limitations}

The only strength of the study is its cross-sectional nature and the large sample observation used for the analyses. However, the following limitations are worthy to be noted. (i) The assessment of health was based on the self-assessment that was not validated by any objective source. Hence, respondents may have given socially desirable responses. (ii) The analyses undertaken was static given the cross-sectional nature of the data. The nature of the data does not give room to a dynamic analysis of the effect of health on labour force participation.

\section{Conclusion}

In conclusion, the study sets out to investigate the effect of health status on labour force participation drawing on data from the General Household Survey (GHS), and a logistic regression model for its analysis. The research was motivated by the keen interest of policymakers all over the world on the benefits of improved health on labour productivity and general economic performance. The assumption is that health workers have both physical and cognitive development pertinent to engaging in the labour market. The results confirm the influence of health status on labour force participation among Nigerian households. Therefore, poor health status reduces labour force participation. Also, we conclude that higher educational attainment improves the probability of participating in the labour force. 


\section{References}

Ajani, O.I.Y. and Ugwu, P.C., 2008. Impact of Adverse Health on Agricultural Productivity of Farmers in Kainji Basin North-Central Nigeria Using a Stochastic Production 'Frontier Approach. Trends Agricultural. Economics. pp. 1: 1-7. https://doi.org/10.3923/tae.2008.1.7. Bound, J., 1991. Self-reported versus objective measures of health in retirement models. Journal of human resource, 26, pp.106-138. https://doi.org/10.2307/145718.

Belachew, T. and Kumar, A., 2014. Examining Association Between Self-Assessed Health Status and Labour Force Participation Using Pooled NHS Data. Australian Bureau of Statistics. Cat. No. 1351.0.55.049.

Becker, G., 1964. Human capital, New York: National Bureau of Economic Research: Distributed by Columbia University Press, 1964.

Cai L., 2007. The Relationship between Health and Labour Force Participation: Evidence from a Panel Simultaneous Equation Model. The University of Melbourne. https://doi.org/10.1016/i.labeco.2009.04.001.

Cai, L. and Kalb G., 2004. Health Status and Labour Force Participation: Evidence from the HILDA Data. Melbourne Institute Working Paper No. 4/04.

Currie, J. and Madrina B. C., 1999. Health, Health Insurance and Labour Market. in O. Ashenfelter and D. Card (eds.), Handbook of Labour Economics, pp. 3310-415.

Dogru, H.G., 2015. The effect of health on labour force participation. Evidence from Turkey. International Journal of Economics and Finance, 7(8), pp.168-181. http://dx.doi.org/10.5539/ijef.v7n8p168.General Household Survey, Panel Wave 2012 2013, Nigerian Bureau of Statistics.

Grossman, M., 1972. On the Concept of health capital and the demand for health, Journal of Political Economy, 8 (2), pp.223-255, https://doi.org/10.1086/259880 .

Grossman, M., 2000. The Human Capital Model of the Demand for Health. National Bureau of Economic Research (NBER) Working Paper Series. Cambridge.

Irequi Bohorquez, A.M. Melo -Becerra, L.A. and Teressa, M.R., 2016. Health status and labour force participation: evidence for urban low and middle-income individuals in Colombia. Portuguese Economic Journal, 15, pp.33 -55. https://doi.org/10.1002/hec.1053. Jimoh, A., 2005. The malaria burden and Agricultural output in Nigeria retrieved from https://www.ajol.info/index.php/agrosh/article/download/39450/36575.

https://doi.org/10.4314/agrosh.v7i1.39450.

Kalwij, A. and Vermeulen, F., 2005. Labour force participation of the elderly in Europe. The importance of being healthy (2015). IZA discussion paper no.1887. Available at https:ssrn.com/abstract $=875383$.

Mushtaq, A., Mohsin, A. and Zaman, K., 2013. Effects of health on changing labour force participation in Pakistan. Springer Plus, 2:610 available at https: www.springer plus.com/content 211/610. https://doi.org/10.1186/2193-1801-2-610.

National Strategic Health Development Plan Framework (2010 - 2015).

Omonona, B.T., Egbetokun, O.A., and Omidele, M.A., 2012. Farmers' health and labour productivity in Osun State, Nigeria. Greener Journal of Agricultural Sciences, 2(4), pp.001009. https://doi.org/10.15580/GJAS.2012.4.07261204.

Novignon, J., Novignon, J. and Arthur, E., 2015. Health status and labour force participation in sub-Saharan Africa: a dynamic data Analysis. African Development Review, 27(1), pp.1426. https://doi.org/10.1111/1467-8268.12119.

Nwosu, C.O., Woolard, I., 2015. Impact on health on labour force participation in South Africa. Working paper 548, Economic Research Southern Africa. https://doi.org/10.1111/saje.12163.

Onyema, J.I. and Nyenke, C.U., 2019. Healthcare, Health status and labour productivity in Nigeria. Kampala International University Journal of Social Sciences, 5(2), pp. 49-58. 
Rolle R.A. and Iseghohi, J.O., 2018. The economic burden of malaria, evidence from Nigeria's data. Amity Journal of Healthcare Management, 3(1), pp.28 -39.

Rolle, R.A. and Onwumah, O.E., 2019. Determinants of Choice of Treatment by Tuberculosis Patients in Nigeria, Amity Journal of Health Care Management, 4 (3) in press. Rolle, R.A., Osaze, D., and Henry, E.A., (2020). What role does health play in enhancing labour productivity in Nigeria? Academic Journal of Economic Studies, 6(2), pp.102 -111. Thomas, B. and Thierry, D., 2006. Disability and the Labour Force Participation of Older Workers: The Importance of Health.

Umoru, D. and Yaqub, J., 2013. Labour productivity and health capital in Nigeria: empirical evidence. International journal of humanities and social sciences, 3(4), pp. 199-221.

United Nations, 2014. The millennium development goals report 2014. United Nations, New York.

World Development Indicators, 2018 available at https://olc. World Bank.org/system/files/Atlas of Sustainable Development Goals.

World Health Organization, 2006. Reproductive Health Indicators: Guidelines for Their generations, interpretation and analysis for Global monitoring. Available at

www.searo.who.int/link files/publications. [Accessed on $18^{\text {th }}$ of May, 2018].

\section{Bio notes:}

Ahuru Rolle Remi, PhD, is a Research Assistant in the Department of Economics, Faculty of Management and Social Sciences at Michael and Cecilia Ibru University, Delta State in Southern Nigeria. He recently completed a PhD Degree in Health Economics from the Department of Economics under the auspices of Center of Excellence in Reproductive Health Innovation (CERHI), University of Benin, Nigeria. His areas of research interest are women's health, disease burden, and Macroeconomics of health implications.

Efegbere Henry Akpojubaro is an Assistant Professor in the Department of Community Medicine, Faculty of Clinical Sciences, College of Medical Sciences, Edo University and Teaching Hospital lyamho, Edo State,Nigeria. His qualifications include but not limited to the following: MBBS; PGD Management; PGD Statistics; MPH; Fellow (PhD equivalence) of Faculty of Public Health and Community Medicine of the National Postgraduate Medical College of Nigeria. He is undergoing training as a PhD student in Health Economics. His areas of research interests: Health Economics; Health Management; Public Health; Community Medicine, among others. 